\title{
Erratum
}

Curr Genet (1992) 22:101-105

\section{A region of heterogeneity adjacent to the $5 s$ ribosomal RNA gene of cereal rusts}

\author{
W. K. Kim ${ }^{1}$, T. Zerucha ${ }^{2}$, and G. R. Klassen ${ }^{2}$ \\ 1 Agriculture Canada, Research Station, 195 Dafoe Road, Winnipeg, Manitoba R3T 2M9, Canada \\ 2 Department of Microbiology, University of Manitoba, Winnipeg, Manitoba R3T 2N2, Canada
}

Received October 28, 1991/January 21, 1992

On page 102 of the paper starting on page 101 of volume 22 there were unfortunately one error. The paragraph concerned is now printed correctly below.

\section{Materials and methods}

Polymerase chain reaction. Total DNA from each organism $(100 \mu \mathrm{g} /$ ml) was diluted 10-fold in TE buffer (10 mM Tris- $\mathrm{HCl}$, pH 7.6, $1 \mathrm{mM}$ EDTA) and PCR was done in a $100 \mu$ reaction volume which included $10 \mu \mathrm{l}$ of $10 \times$ Perkin Elmer Cetus PCR buffer $(100 \mathrm{mM}$ Tris-HCl, $\mathrm{pH} 8.3 ; 500 \mathrm{mM} \mathrm{KCl} ; 15 \mathrm{mM} \mathrm{Mg} \mathrm{Cl}_{2}, 0.1 \%$ gelatin), $8 \mu \mathrm{l}$ of dNTP mix contributing $200 \mu \mathrm{M}$ of each nucleotide to the final concentration of the reaction mixture, $1.5 \mu \mathrm{l}(10$ pmole $)$ of each primer [primer Q (dACGCCTCTAAGTCAGAAT) was based on an yeast sequence (Gutell and Fox 1988) while primer Y (dTCGCAGAGCGAACGGGAT) was based on published $5 s$ sequences (Wolters and Erdman 1988)], $1.0 \mu \mathrm{l}$ (10 ng) of template DNA solution; $0.5 \mu \mathrm{l}$ ( 2.5 units) of $T a q$ polymerase, and $77.5 \mu l$ of ultrapure, sterilized water. The DNA was heated for $5 \mathrm{~min}$ at $94^{\circ} \mathrm{C}$ just before addition to the reaction solution. Fifty $\mu$ l of mineral oil were placed over the reaction solution and then the reaction tube was subjected to a heating and cooling protocol in a DNA thermal cycler (Perkin Elmer Cetus Instruments) using the step cycle program (Myers et al. 1989). The amplification was started with the denaturation step at $94^{\circ} \mathrm{C}$ for $1 \mathrm{~min}$, followed by annealing at $55^{\circ} \mathrm{C}$ for $1 \mathrm{~min}$ and polymerization at $72^{\circ} \mathrm{C}$ for $1 \mathrm{~min}$. The sequence was repeated for 27 cycles and at the end of the cycle, the polymerization step at $72^{\circ} \mathrm{C}$ was extended for $5 \mathrm{~min}$. The amplification products were electrophoresed directly on $1.3 \%$ agarose gels or first precipitated in ethanol and then resuspended to TE buffer before electrophoresis (Kim et al. 1988). The PCR product yield was sufficient for staining of bands in gels with ethidium bromide and for restriction digestion. 